\title{
Biochemical state of the vitreous humour of infants at necropsy
}

\author{
PETER G. F. SWIFT, ERIC WORTHY, and JOHN L. EMERY \\ From The Children's Hospital, Sheffield
}

\begin{abstract}
Swift, P. G. F., Worthy, E., and Emery, J. L. (1974). Archives of Disease in Childhood, 49, 680. Biochemical state of the vitreous humour of infants at necropsy. Biochemical analysis of the vitreous humour in 80 infants brought to necropsy, including 18 in whom terminal plasma levels were known, indicates that sodium and urea levels closely reflect ante-mortem plasma values. With increasing time, post-mortem vitreous sodium and glucose concentrations diminish, whereas urea and magnesium rise. Vitreous magnesium levels are age related. Chemical analysis of vitreous humour is thus a valid adjunct to the post-mortem examination and may be important in the study of unexpected deaths in infancy.
\end{abstract}

The vitreous humour forms a relatively isolated pool of fluid uncontaminated by erythrocytes, whose chemical composition mirrors plasma (Pirie and van Heyningen, 1956; Davson, 1972) and changes more slowly after death than blood or CSF (Naumann, 1959). Vitreous humour chemistry has been used in adults to determine the time of death (Adelson et al., 1963), to help uncover metabolic disturbances present at the time of death, and as an aid in the diagnosis of drug ingestion (Coe and Sherman, 1970).

Between the ages of 2 weeks and one year, almost half of the children who die are found unexpectedly dead at home (Emery, 1973). Many of these fall into the category of the unexpected cot death and the biochemical state of these children is largely unknown. The occasional use of the vitreous humour in adults led us to study the possible use of this fluid in assessing the agonal and ante-mortem biochemical state of infants. Using this fluid in infants we found that many of the levels were grossly abnormal and a report by Sturner and Dempsey (1973) showed similar findings. In order to interpret these findings it was first necessary to see whether or not the vitreous humour in the infant behaves similarly to that in adults, and to relate the post-mortem state of the vitreous to known plasma biochemistry in children before death.

Material and methods

80 children coming to necropsy were used. Vitreous

Received 19 February 1974. humour was aspirated from the centre of the eyeball through the sclera from the direction of the outer canthus using a $5 \mathrm{ml}$ syringe and a 21 gauge disposable needle. By this means 50 to $800 \mu$ l fluid was obtained. After aspiration, the same volume of water was reinjected into the eye to maintain its turgidity. The vitreous was aspirated from one eyeball as soon as possible after the child had been admitted to the mortuary and a similar specimen was taken from the other eyeball just before the child was to be taken from the mortuary for burial after necropsy. In a small initial series, fluid was obtained from both eyes at the same time to confirm reproducibility of the technique.

Analyses were performed using the routine hospital methods for sodium using an integrating flame photometer EEL 227, magnesium and calcium by an atomic absorption spectrophotometer EEL 140, urea by urease and Berthelot reactions, and glucose by a modified glucose-oxidase peroxidase method. The vitreous humour composition was analysed in 18 children on whom clinical estimations had been done before death.

\section{Results}

Simultaneous aspiration of both eyes. In 5 cases samples were taken from both eyes at the same time. There was no significant difference in sodium, urea, calcium, and magnesium levels in the two eyes.

Sodium. 138 vitreous sodium determinations were made from 80 children.

Ante- and post-mortem levels. In 18 children the levels of plasma sodium during the 24 hours before 
TABLE I

Ante-mortem plasma sodium and post-mortem vitreous sodium levels in 18 children

\begin{tabular}{|c|c|c|c|c|c|}
\hline Age & $\begin{array}{l}\text { Ante-mortem } \\
\text { plasma sodium } \\
\text { (mEq/l.) }\end{array}$ & $\begin{array}{l}\text { Hours before } \\
\text { death }\end{array}$ & $\begin{array}{l}\text { Post-mortem } \\
\text { vitreous sodium } \\
\text { (mEq/l.) }\end{array}$ & $\begin{array}{c}\text { Hours after } \\
\text { death }\end{array}$ & $\begin{array}{c}\text { Difference } \\
\text { (mEq/l.) }\end{array}$ \\
\hline $\begin{array}{l}\text { Hypernatraemic group } \\
4 \mathrm{yr} \\
12 \mathrm{dy} \\
15 \mathrm{wk} \\
22 \mathrm{wk} \\
14 \mathrm{mth} \\
26 \mathrm{wk} \\
\text { Normonatraemic group } \\
16 \mathrm{wk} \\
42 \mathrm{wk} \\
5 \mathrm{wk} \\
11 \mathrm{yr} \\
19 \mathrm{mth} \\
\text { Hyponatraemic group } \\
7 \mathrm{yr} \\
18 \mathrm{wk} \\
5 \mathrm{dy} \\
4 \mathrm{wk} \\
10 \mathrm{dy} \\
3 \mathrm{wk} \\
21 \mathrm{mth}\end{array}$ & $\begin{array}{l}181 \\
167 \\
156 \\
153 \\
150 \\
144 \\
\\
137 \\
137 \\
137 \\
134 \\
132 \\
\\
127 \\
126 \\
126 \\
125 \\
125 \\
120 \\
113\end{array}$ & $\begin{array}{r}1 \\
22 \\
9 \\
5 \\
24 \\
3 \\
\\
6 \\
6 \\
24 \\
3 \\
4 \\
22 \\
\\
24 \\
1 \\
3 \\
12 \\
6 \\
24 \\
5\end{array}$ & $\begin{array}{l}179 \\
150 \\
152 \\
164 \\
158 \\
144 \\
\\
139 \\
132 \\
143 \\
146 \\
126 \\
\\
110 \\
127 \\
129 \\
116 \\
116 \\
129 \\
115\end{array}$ & $\begin{array}{r}25 \\
29 \\
27 \\
38 \\
48 \\
65 \\
\\
40 \\
35 \\
72 \\
18 \\
6 \\
\\
31 \\
2 \\
17 \\
75 \\
83 \\
10 \\
3\end{array}$ & $\begin{array}{l}-2 \\
-17 \\
-4 \\
+11 \\
+8 \\
0 \\
+2 \\
-5 \\
+6 \\
+12 \\
-6 \\
-17 \\
+1 \\
+3 \\
-9 \\
-9 \\
+9 \\
+2\end{array}$ \\
\hline
\end{tabular}

death were compared with the vitreous humour levels after death (Table I). The children were divided into three groups: those known to be hypernatraemic, those apparently normonatraemic, and those hyponatraemic. Of those children known to be hypernatraemic before death, the post-mortem vitreous level reflected this state in all cases. The children known to be hyponatraemic before death all had low vitreous sodium levels. Of the normonatraemic children, 2 remained at 'normonatraemic' levels and 2 showed an increase in vitreous sodium in the post-mortem specimen. In both of these children, however, the ante-mortem plasma electrolytes were determined at a time when the children were under intensive intravenous fluid therapy for the treatment of cardiac and peripheral circulatory failure.

Post-mortem changes. There were 47 children from whom separate eye specimens were obtained at different intervals after death. $38(78 \%)$ had a lower sodium concentration in the second vitreous sample (Fig. 1).

The normal plasma sodium in this hospital in the age group of the children studied ranges from 129 to $141 \mathrm{mEq} / \mathrm{l}$. When the initial vitreous specimen had a concentration of less than $141 \mathrm{mEq} / \mathrm{l}$. the subsequent specimen showed a fall in almost all cases and the rate of decrease in concentration of sodium varied from 0.05 to $0.65 \mathrm{mEq} / \mathrm{l}$. per hr. When the initial sodium level was above $141 \mathrm{mEq} / 1$. the subsequent level appeared to be unpredictable. In

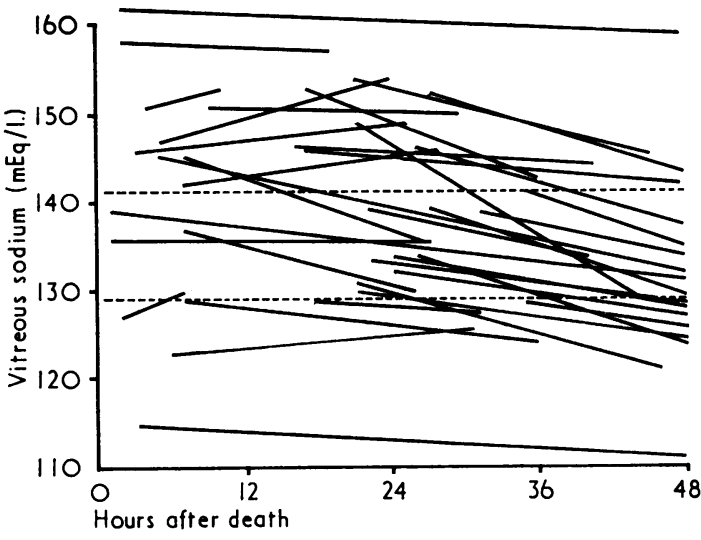

FIG. 1.-Vitreous sodium level related to time after death in 36 children. Lines join the levels in individual children, one specimen being taken from one eye and the other from the opposite eye later.

no child was the initial sodium level within the normal range and the subsequent level above the normal range for plasma.

\section{Urea.}

Ante- and post-mortem levels. In 19 children ante-mortem plasma and the post-mortem vitreous urea levels were obtained (Fig. 2). There was no difference in the vitreous urea level as compared with the ante-mortem plasma urea level when ante-mortem levels were over $60 \mathrm{mg} / 100 \mathrm{ml}$. 


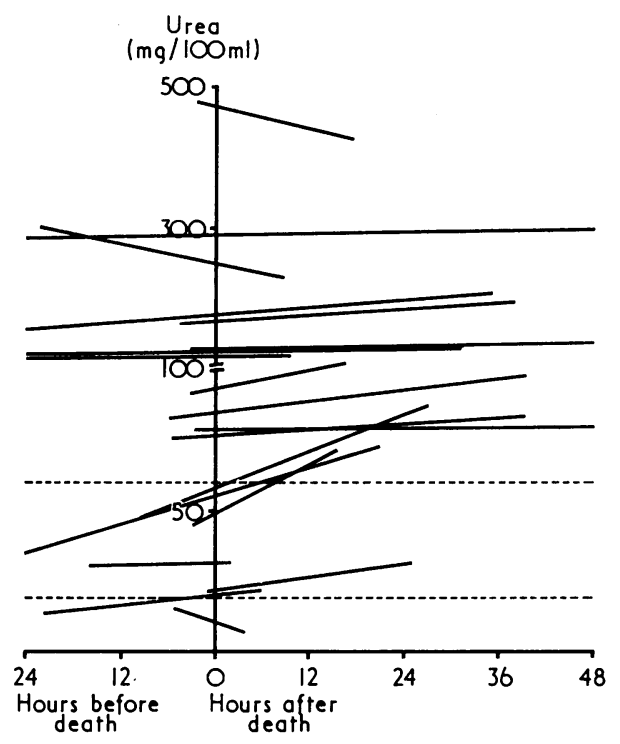

FIG. 2.-Levels of plasma urea before death related to the vitreous levels after death in 19 children. Lines join the ante- and post-mortem levels in individual cases.

There were higher vitreous levels in all of those whose plasma urea fell within the normal range. In 3 children with clinical evidence of terminal renal failure the post-mortem level had risen to between 70 and $90 . \mathrm{mg} / 100 \mathrm{ml}$ at necropsy.

Post-mortem changes. In 49 children two separate post-mortem specimens were analysed from different eyeballs. $37(75 \%)$ showed a rise with increasing time post mortem. This rise varied from 0.081 to $0.62 \mathrm{mg} / 100 \mathrm{ml}$ per hour in the first 48 hours after death (Fig. 3).

Magnesium. In 38 children 2 specimens at different intervals post mortem were obtained for measurement of vitreous magnesium. Two-thirds of these showed a slow increase in concentration, varying from 0.003 to $0.09 \mathrm{mg} / 100 \mathrm{ml}$ per hour. Many of the vitreous magnesium levels were higher than the generally accepted normals for plasma magnesium and the vitreous : plasma ratio appears to be higher in the younger than in the older infant, though no ante-mortem magnesium levels were known. The levels of vitreous magnesium related to age are shown in Fig. 4.

Calcium. Vitreous calcium measured in 43 cases showed no age relation as with magnesium,

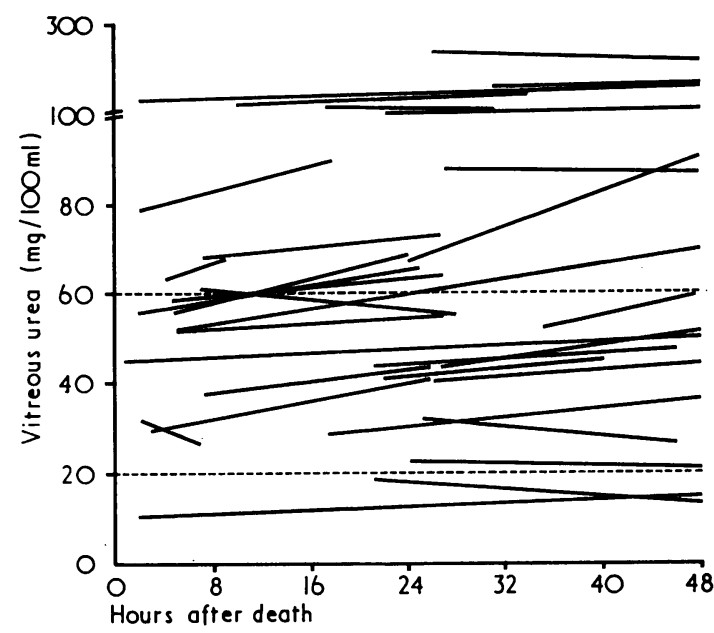

FIG. 3.-Vitreous urea level related to time after death in 31 children. Lines join the levels in individual children, one specimen being taken from one eye and the other from the opposite eye later.

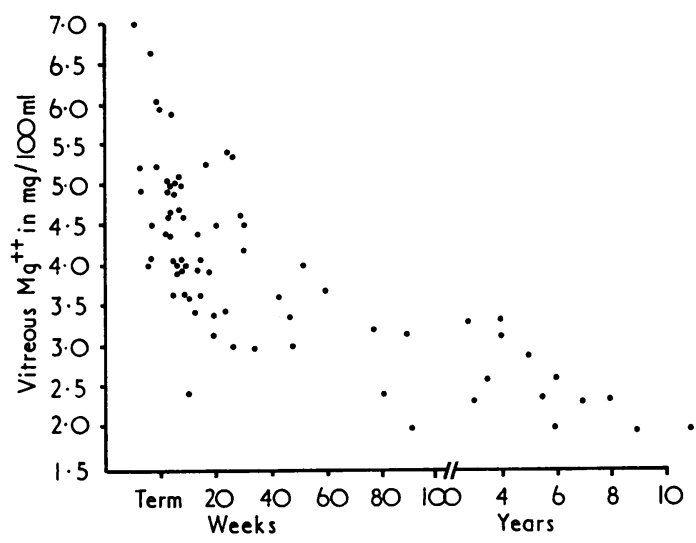

FIG. 4.-Level of vitreous magnesium related to the age of the child at death in 74 children.

and showed no consistent rise or fall in the second post-mortem specimen.

Ante- and post-mortem level. Ante-mortem plasma levels were available in only 5 children during the 48 hours preceding death. The vitreous calcium concentration was in close agreement with that of the ante-mortem plasma levels. The widest difference was $0.7 \mathrm{mg} / 100 \mathrm{ml}$, except in one case showing a post-mortem rise of $2.4 \mathrm{mg} / 100 \mathrm{ml}$ in a child from whom the post-mortem specimen was taken 70 hours after death (Table II). 
TABLE II

Ante-mortem plasma calcium and post-mortem vitreous calcium levels in 5 children

\begin{tabular}{|c|c|c|c|c|c|}
\hline Age & $\begin{array}{l}\text { Ante-mortem } \\
\text { plasma calcium } \\
(\mathrm{mg} / 100 \mathrm{ml})\end{array}$ & $\begin{array}{c}\text { Hours before } \\
\text { death }\end{array}$ & $\begin{array}{l}\text { Post-mortem } \\
\text { vitreous calcium } \\
(\mathrm{mg} / 100 \mathrm{ml})\end{array}$ & $\begin{array}{c}\text { Hours after } \\
\text { death }\end{array}$ & $\begin{array}{l}\text { Difference } \\
(\mathrm{mg} / 100 \mathrm{ml})\end{array}$ \\
\hline $\begin{array}{l}3 \mathrm{dy} \\
3 \mathrm{wk} \\
5 \mathrm{mth} \\
21 \mathrm{mth} \\
4 \mathrm{yr}\end{array}$ & $\begin{array}{r}5 \cdot 9 \\
8 \cdot 3 \\
7 \cdot 3 \\
8 \cdot 6 \\
10 \cdot 7\end{array}$ & $\begin{array}{r}48 \\
24 \\
5 \\
48 \\
2\end{array}$ & $\begin{array}{r}5 \cdot 2 \\
8 \cdot 9 \\
6 \cdot 8 \\
11 \cdot 0 \\
11 \cdot 0\end{array}$ & $\begin{array}{l}51 \\
10 \\
38 \\
70 \\
25\end{array}$ & $\begin{array}{r}-0.7 \\
+0.6 \\
-0.5 \\
+2.4 \\
+0.3\end{array}$ \\
\hline
\end{tabular}

Post-mortem changes. Of 20 children in whom the vitreous samples were obtained at different times after necropsy, 10 showed an increase and 10 a decrease, the rate of change varying from almost nil to $2 \mathrm{mg} / 100 \mathrm{ml}$ in 24 hours.

Glucose. Glucose levels were measured in 25 children. In 11 of these the concentration was less than $10 \mathrm{mg} / 100 \mathrm{ml}$.

Ante- and post-mortem levels. In 8 children ante-mortem plasma glucose levels were available for comparison with vitreous levels (Table III). In 7 cases the vitreous level was markedly lower than plasma. In 1 case the vitreous glucose was higher than plasma; the plasma glucose had been raised (to $880 \mathrm{mg} / 100 \mathrm{ml}) 48$ hours before death.

Post-mortem changes. In 8 out of 9 children in whom levels were determined at different intervals of time, a fall in glucose level was apparent (Fig. 5). The rate of fall varied from 0.21 to $1.6 \mathrm{mg} / 100 \mathrm{ml}$ per hour. The case showing a rise in vitreous glucose had been given an intravenous glucose infusion just before death.

The relation between ante-mortem and postmortem levels of urea and sodium are illustrated by the following two case reports.

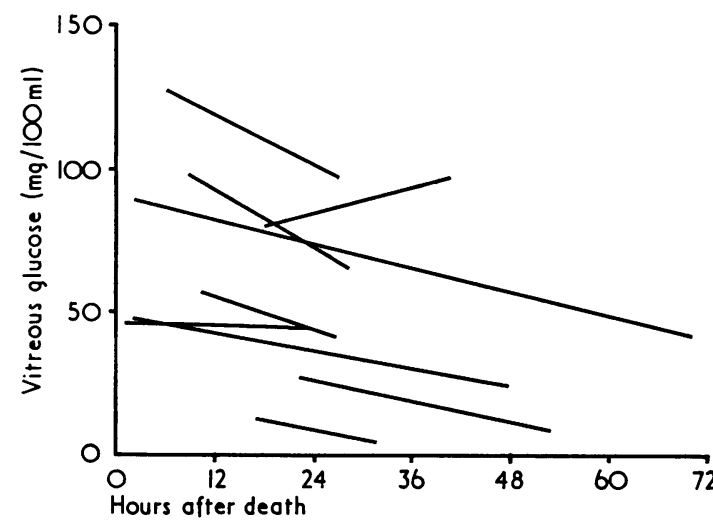

FIG. 5.-Vitreous glucose levels related to time after death in 9 children.

Case 1. A girl aged 9 weeks with proven Turner's syndrome was found lifeless in her cot at home after 3 days of diarrhoea, vomiting, and progressive respiratory distress. On admission to hospital cardiac rhythm was restored and artificial ventilation instituted. She was hypernatraemic, acidotic, and oliguric. Immediately before her death, 32 hours after admission, she had received intravenous frusemide and mannitol, in addition to a hypotonic saline infusion.

Fifteen hours post mortem the sodium and urea concentrations in the vitreous were similar to the plasma

TABLE III

Ante-mortem plasma glucose and post-mortem vitreous glucose levels in 8 children

\begin{tabular}{|c|c|c|c|c|c|}
\hline Age & $\begin{array}{l}\text { Ante-mortem } \\
\text { plasma glucose } \\
(\mathrm{mg} / 100 \mathrm{ml})\end{array}$ & $\begin{array}{l}\text { Hours before } \\
\text { death }\end{array}$ & $\begin{array}{l}\text { Post-mortem } \\
\text { vitreous glucose } \\
(\mathrm{mg} / 100 \mathrm{ml})\end{array}$ & $\begin{array}{c}\text { Hours after } \\
\text { death }\end{array}$ & $\begin{array}{l}\text { Difference } \\
(\mathrm{mg} / 100 \mathrm{ml})\end{array}$ \\
\hline $\begin{array}{l}1 \mathrm{dy} \\
5 \mathrm{dy} \\
12 \mathrm{dy} \\
2 \mathrm{mth} \\
4 \mathrm{mth} \\
5 \mathrm{mth} \\
21 \mathrm{mth} \\
11 \mathrm{yr}\end{array}$ & $\begin{array}{r}100 \\
82 \\
140 \\
62 \\
250 \\
192 \\
94 \\
277\end{array}$ & $\begin{array}{r}3 \\
3 \\
22 \\
12 \\
6 \\
5 \\
5 \\
4\end{array}$ & $\begin{array}{r}26 \\
14 \\
102 \\
<10 \\
97 \\
<10 \\
245 \\
84\end{array}$ & $\begin{array}{r}32 \\
17 \\
9 \\
15 \\
40 \\
38 \\
3 \\
18\end{array}$ & $\begin{array}{l}-74 \\
-68 \\
-38 \\
-52 \\
-153 \\
-180 \\
+151 \\
-193\end{array}$ \\
\hline
\end{tabular}




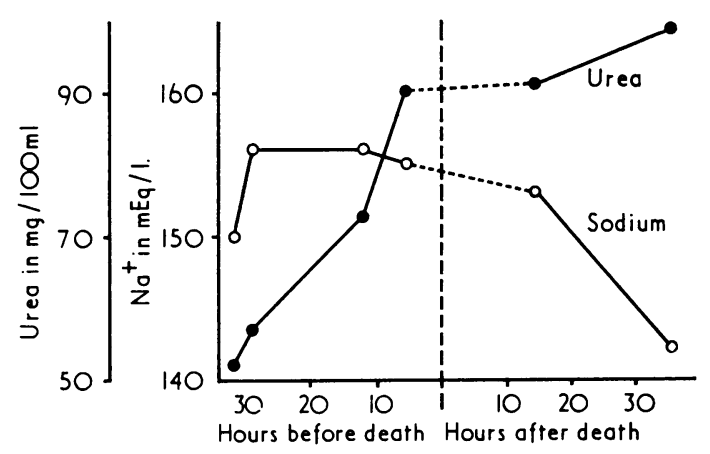

Fig. 6.-Case 1. Plasma levels of sodium and urea at different times before death and vitreous levels after death.

concentrations 5 hours ante mortem (Fig. 6). The vitreous levels at 36 hours had altered markedly, but still remained in the hypernatraemic uraemic range.

Case 2. A girl born at 37 weeks' gestation was admitted 9 days later with a short history of anorexia and respiratory distress. She was dehydrated, semiconscious, and convulsing. Investigation revealed uraemia and hypernatraemia. Intravenous therapy failed to improve the biochemical state and she died oedematous and scleremic. Post-mortem examination revealed bilateral hydronephrosis, urethral obstruction, and subarachnoid haemorrhage.

Vitreous sodium and urea levels were lower than the (22 hour) ante-mortem plasma concentrations, but remained in the hypernatraemic uraemic range (Fig. 7). An expanded less hyperosmolar extracellular fluid would be expected in an infant rapidly becoming oedematous, and the vitreous perhaps reflects this terminal change in fluid compartments.

\section{Discussion}

Naumann (1959) suggested that post-mortem changes in vitreous sodium, chloride, urea, and

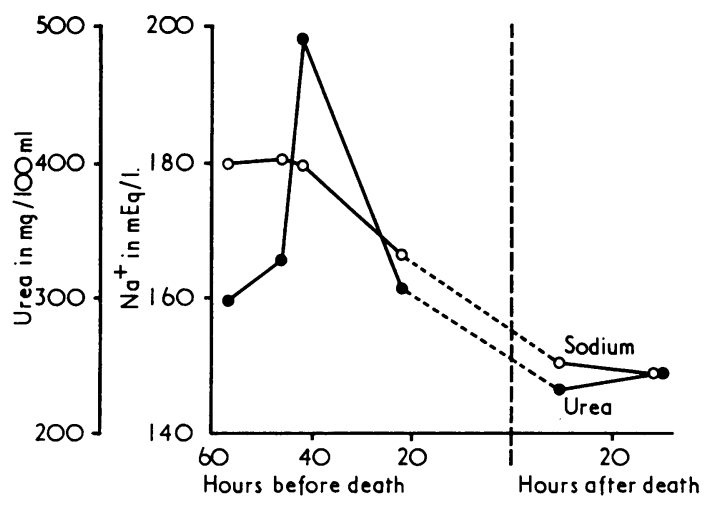

Fig. 7.-Case 2. Plasma levels of sodium and urea at different times before death and vitreous levels after death. Note the urea scale differs from that in Fig. 6 . glucose concentrations were less profound than in blood or CSF. Vitreous sodium and chloride levels remain stable for up to 30 hours (Jaffe, 1962) and the stability also applies to urea (Leahy and Farber, 1967).

It was shown that in 30 adults dying with recognized abnormalities of serum sodium, measured in the 24 hours preceding death, and in 43 with raised blood urea nitrogen, the post-mortem vitreous sodium and urea levels closely reflected the ante-mortem values (Coe, 1969). Glucose levels were shown to diminish erratically but were of value in cases of hyperglycaemia. Low calcium levels in the blood were often not reflected in the vitreous humour. Results in the present study in infants and children are similar to those of Coe (1969) in adults.

The finding that vitreous sodium and urea levels remain relatively stable for 24 hours after death, and that these reflect the ante-mortem state of the child, makes the examination of the vitreous humour a valid and essential part of the paediatric postmortem necropsy technique. In our known clinical cases of hypernatraemia and hyponatraemia the vitreous results consistently confirmed these abnormalities and the same applied to uraemia.

The estimation of magnesium in children requires further study. Plasma magnesium concentrations are difficult to interpret as they do not reflect the total body reserves of the cation. The concentrations measured in the present study showed a marked age dependency, with the vitreous : plasma ratio approaching unity only in older children. The possible pathological significance of some cases where levels fall well outside this age distribution curve is uncertain at present, and we would be unwise to interpret levels at the present time. Also, the number of cases in which we have studied the calcium level and the variability of the results leave the situation still inadequately explored.

Glucose levels in the serum and CSF fall rapidly after death due to continuing tissue glycolysis (Naumann, 1959). This study confirms that vitreous glucose levels diminish after death but the rate of fall is relatively slow. Low glucose levels measured shortly after death require further investigation in view of the possibility of deaths with hypoglycaemia in infancy (Porter, 1972).

Our results help to validate the work of Sturner and Dempsey (1973), who analysed vitreous humour taken from 67 infants dying suddenly from known or unknown causes. No ante-mortem biochemical data were available making the importance of their findings debatable, as all previous reported studies had been performed on adults. Only one of their 
cases had a significant combined hypernatraemic uraemia (sodium $>150 \mathrm{mEq} / 1$. and urea $>100$ $\mathrm{mg} / 100 \mathrm{ml}$ ). However, 20 of the 33 infants dying with gastrointestinal or respiratory illnesses showed abnormal electrolyte patterns. It was of interest that in their group of 16 sudden deaths from undetermined causes ('cot deaths') the vitreous electrolytes showed no abnormalities. It is clear that examination of the vitreous humour, particularly with measurement of sodium and urea, can provide chemical evidence of pre-existing electrolyte disturbances and constitutes a highly desirable investigation in children found unexpectedly dead.

We acknowledge the assistance of Mrs. Pat McWeeny who is supported by the Foundation for the Study of Infant Deaths and of 'Bert and Sylvia' in the mortuary.

\section{REFERENCES}

Adelson, L., Sunshine, I., Rushforth, N. B., and Mankoff, M. (1963). Vitreous potassium concentration as an indicator of post mortem interval. Fournal of Forensic Sciences, 8, 503.
Coe, J. I. (1969). Post mortem chemistries on human vitreous humor. American fournal of Clinical Pathology, 51, 741.

Coe, J. I., and Sherman, R. E. (1970). Comparative study of post mortem vitreous humor and blood alcohol. Fournal of Forensic Sciences, 15, 185.

Davson, H. (1972). The Physiology of the Eye, 3rd ed., p. 32. Churchill Livingstone, Edinburgh and London.

Emery, J. L. (1973). Unexpected deaths in infants. Nursing Times, April 12th, p. 474.

Jaffe, F. A. (1962). Chemical post-mortem changes in the intraocular fluid. fournal of Forensic Sciences, 7, 231.

Leahy, M. S., and Farber, E. R. (1967). Postmortem chemistry of human vitreous humor. Fournal of Forensic Sciences, 12, 214.

Naumann, H. N. (1959). Postmortem chemistry of the vitreous body in man. Archives of Ophthalmology, 62, 356.

Pirie, A., and van Heyningen, R. (1956). Biochemistry of the Eye, p. 242. Blackwell, Oxford.

Porter, A. M. W. (1972). Sudden Death in Infancy. Sir Samuel Bedson Symposium, Addenbrooke's Hospital, Cambridge, p. 74. Ed. by F. E. Camps and R. G. Carpenter. Wright, Bristol.

Sturner, W. Q., and Dempsey, J. L. (1973). Sudden infant death: chemical analysis of vitreous humor. Fournal of Forensic Sciences, 18, 12.

Correspondence to Professor J. L. Emery, The Children's Hospital, Western Bank, Sheffield S10 2TH. 